\title{
ОСОБЛИВОСТІ МОТИВАЦІЇ ДО НАВЧАННЯ СТУДЕНТІВ ПЕРШОГО КУРСУ ПСИХОЛОГІЧНИХ СПЕЦАЛЬНОСТЕЙ
}

УДК: 159.947 .5

\author{
Яскевич Ольга Іаорівна \\ Кандидат психологічних наук, доцент, кафедра \\ психології та психотерапії Украӥнського католи- \\ цъького університету, м. Львів (Україна)

\section{Миколайчук Мар'яна Ігорівна} \\ Кандидат психологічних наук, доцент, кафедра \\ психології та психотерапії Українського католи- \\ цьького університету, м. Львів (Украӥна)
}

\begin{abstract}
Анотація. В статті здійснено спробу описати особливості мотивації студентів першого курсу до навчання на психологї та проаналізувати їх розвиток у контексті інтерперсонального підходу. Показано, щзо навчальна мотиваџія студента є суб'єктивним відображенням можливостей $i$ дефіцитів його $Я$, які склалися в конкретному інтерперсональному полі між ним та викладацьким колективом. В свою чергу, проблемна мотивація студента до навчання, яка може проявлятися у вигляді інфантильного, цчинічноспоживацького, розважально- чи формально-байдужого ставлення, розглядається як інтерперсональна проблема, нездатність університетського середовища дати адекватний відгук на поведінку студента, віддзеркалюючи йому його непевність чи амбівалентність, або підтримати його прояви експлорації в бік автономії та інакшості.
\end{abstract}

Ключові слова: мотиваційний профіль, его-ідентичність, інтерперсональне поле, розвитковий об'єкт.

Постановка проблеми. Проблема мотивації студентів до навчання віддавна є предметом пильної уваги та дослідницького інтересу психологів, що працюють у сфері педагогічної психології [4]. Разом з тим, іiі неможливо вичерпати, оскільки з кожним новим поколінням разюче змінюється мотиваційний про- філь студентів, з'являються нові тенденції в ставленні до навчання, які раніше були непроявлені або недопустимі, наприклад, відверто споживацький підхід у сенсі пошуку прагматично-ринкових або розважальних цінностей, брак дистанції в стосунку до викладачів, наївне нерозуміння принципів субординації. 3 ін- 
шого боку, навчання на психологічних спеціальностях має свою специфіку, адже психологія належить до тих галузей гуманітарних знань, які неминуче спричиняють персональну емоційну заангажованість, а, отже, викликають не тільки гострий інтерес, але й тривогу, яка блокує пізнання та провокує найрізноманітніші захисні стратегії $[2,4,8]$.

Аналіз останніх досліджень і публікацій. Мотивація студента до фахового навчання є явищем об'ємним. Вона не просто корелює з якістю засвоєння професійних знань, але й розкриває динамічну складову інтерналізаційних процесів у широкому - розвитковому значенні цього терміну [11]. Йдеться про вік, безпосередньою психосоціальною задачею якого, за Еріксоном, є формування ідентичності [12]. Фах і фахове навчання слугують своєрідною «упаковкою особистості», з іiї індивідуальними сплетіннями бажань, страхів, психічних ресурсів та дефіцитів. Інакше кажучи, професія концентрує в собі ідентичність людини, а професійне навчання стає прекрасним майданчиком для его-інтеграції. Оволодіння фахом - це також оволодіння собою, оформлення душевного сум'яття, окреслення Я, що буквально штормить і розмивається від некерованої внутрішньої революції, «позичання» соціально прийнятної мови для озвучення свого внутрішнього світу. Вдалий вибір - це шанс безболісно знайти своє доросле Я і уникнути екстремальних шляхів (душевних драм, маргінальних субкультур, сумнівних компаній, не- безпечних захоплень, радикальної діяльності та рішень) $[1,10]$. Адже підлітка - а студент першого курсу ВУЗу потрапляє в віковий період, означений Еріксоном як пубертат та юність, - змагає самовідчуття, що ціла його ідентичність починає розхитуватись під тиском тілесних революцій [12]. Підліток намагається збирати іiі докупи, формулювати про себе якісь ідеї, шукати визначень і самовизначатись 3 усіх можливих питань, випробовувати їх у дії та тривожно спостерігати за ефектом, як його сприймають і приймають інші. Цей процес соціальної референції пронизаний найрізноманітнішими нарцистичними страхами, адже підліток сам до кінця не знає, як він ставиться до всього, що експонує іншим, чи те, що він думає, робить і почуває, є насправді валідним і вартісним. Власне для валідизації та наділення сенсом своїх переживань йому відтепер вже не досить уяви, як це було в ранньому пубертаті, йому потрібне реальне дзеркало, i, як стверджує Дольто, він його знаходить у реакціях оточення $[1,3,7]$.

Найбільший ризик тут полягає в тому, що підліток відчайдушно потребує наближатися до людей, але може зазнати в цьому наближенні та саморозкритті разючого фіаско. Його найбільший і часто виправданий страх полягає в тому, що його відштовхнуть разом 3 його мріями, непевностями та ідеями. В такому випадку змодельовані уявлення про себе та про стосунок не пройдуть апробації реальністю, і підліток в силу своєї вікової, а може, та- 
кож особистісної нарцистичної вразливості ризикує відступити назад, забитись у віртуальну ущелину і звідти задовольняти свої потреби в спілкуванні та ідентифікації. Звідти це точно безпечніше і контрольованіше. В ютюб-каналах та соцмережах можна штучно конструювати свою ідентичність, видаляти іiі цілими кусками або навіть цілком, позбуватись небажаних інших, завести ще одну альтернативну ідентичність тощо. Можна вдатися до гри в так-ніби особистість, особистість, яка насправді не має ваги, а натомість є безтілесною, уявною, гнучко-мінливою і постмодерною, що не встигає загуснути, залишаючись тоненькою психічною мембраною. Тут доречно згадати про психоаналітичну концепцію «другої шкіри» Е. Бік. Ф. Дольто знаходить дуже влучну метафору, коли порівнює підлітка та лангуста, який скидає панцир. «Коли лангуст голий, - пише вона, - в час своєї максимальної вразливості, він мусить забитися куди -небудь в безпечну ущелину між камінням, подалі від світу. Якщо його все ж поранять, то шрам залишиться назавжди, просто пізніше його надійно приховає вирослий панцир» [1]. Залишається сподіватися, що підліток не втратить інтересу до людей, врешті таки здолає свій підлітковий марафон і знайде своє місце в соціальній структурі. Так найчастіше і буває, що підлітку доводиться розчаровувати когось, розчаровуватись самому i знову пробувати наблизитись до іншого в спільних очікуваннях. Якщо ж він не ризикне більше шукати спільний знаменник, вирішить, що інші принципово недоступні, тоді його цікавитимуть виключно собі подібні люди. Він комунікуватиме і любитиме тільки тих, хто так само думає, так само почуває, хто «зліплений з того самого тіста». По суті, він спілкуватиметься сам з собою, як Нарцис з своїм відображенням у воді, і не терпітиме жодних натяків, коли партнер проявлятиме неминучу інакшість [10, $15]$.

Отже, формування ідентичності відбувається виключно в інтерперсональному полі i, згідно з Салліваном, пов'язане 3 комунікативними та ідентифікаційними механізмами [7, 9]. Для студента цим інтерперсональним полем є стосунок з навчальним закладом, взаємодія з його структурою в цілому та окремими фігурами зокрема, і цей стосунок має виразну нарцистичну характеристику в тому сенсі, що студент використовує його для регуляції, консолідації та диференціації власного Селф. В наш час, коли культура жбурляє підлітків у відкрите море, начинене рекламними спокусами і позбавлене жорстких етичних табу, підліток опиняється в ситуації, де надто багато залежить від вирозумілості батьків і від його власної інтуїції. До певної міри, університетське середовище може слугувати підлітку майданчиком для ініціаційних практик, які архаїчна культура в обов'язковому порядку влаштовувала кожному новому поколінню, сепаруючи їх від батьківського дому та форматуючи досвід загартовування у випробуван- 
нях під пильним оком чужих дорослих. Інша справа, що викладачі не завжди коректно оцінюють свою роль для студентів як розвиткових об'єктів чи Селф-об'єктів у розумінні Когута, протиставляючи університет шкільній опікаючій рамці, або, навпаки, вдаючись до безпосередньої участі в студентському житті. Натомість підліток з огляду на вік потребує не стільки прямого хендлінгу, скільки коректної реакції, яка віддзеркалить йому його ж власну поведінку і в такий спосіб валідизує його внутрішні переживання [10]. Адже основне завдання пубертату - навчитись розрізняти свої забарвлені бажаннями та страхами уявлення та реальний стан речей. Знову ж таки, абстинентна позиція дорослих і депривація потреби в залежності та регресивних відреагуваннях для підлітка нестерпна ще більше, ніж надмірна опіка, адже пов'язана з недоступністю об' $€-$ кта, що є головною стосунковою перешкодою, коли йдеться про потребу повторного наближення. Малєр відносить її до кульмінації сепараційної кризи спочатку в період 1,5-2,5 роки, а потім у пубертаті [5,14]. Треба пам'ятати, що студент першого курсу вже не має дитячої безпосередності в поведінці, когнітивні здатності дозволяють йому великою мірою покладатися на спостереження і самоспостереження. Він сканує оточення в пошуках доступного об'єкта, якого може наділити для себе особливим авторитетом (потреба в ідеалізації за Когутом) i, як ніколи, цінує ненав'язливу доброзичливу уважність до себе. Часом обраний до- рослий навіть не здогадується, до якої міри впливає на підлітка та слугує ідентифікаційною моделлю, надто якщо врахувати незграбність підлітка, невміння проявити вдячність, яку він приховує за фасадною грубістю або демонстративною байдужістю [1]. В цьому сенсі набуває значення класична педагогічна аксіома про спільну для всіх рамку та індивідуальний підхід в їі межах $[5,8]$.

Наше припущення полягає в тому, що навчальна мотивація студента є суб'єктивним відображенням можливостей і дефіцитів його власного Я, які склалися в конкретному інтерперсональному полі між ним та викладацьким колективом. 3 цієї точки зору, проблемну мотивацію студента до навчання, яка може проявлятися, наприклад, у вигляді інфантильного, цинічно-споживацького, розважальномедійного чи формально-байдужого ставлення, можна розглядати як інтерперсональну проблему, нездатність університетського середовища дати адекватний відгук на поведінку студента, віддзеркалюючи йому його непевність або амбівалентність, або підтримати його прояви експлорації в бік автономії та інакшості [3, 15]. Тут 3'являється новий ракурс проблеми: наскільки університетська структура має чутливість до змін, які привносять 3 собою нові покоління, що здоміновує у відповідь - тривога чи схвалення. Постають питання, як поєднати гнучкість 3 класичною університетською традицією, як в епоху медіа вберегти цінність і глибину знання, яке передається 
через живий контакт. Зрештою, всі вони зводяться до одного: як створити спільний життета працездатний простір у стосунку з студентами, який буде майданчиком для обміну та креативних смислів, а не лінією взаємного опору, тиску, тривожної інтоксикації, дифузій ідентичності та злиття.

Метою даної статті $\epsilon$ спроба описати особливості мотивації студентів першого курсу до навчання на психології та проаналізувати їх розвиток у контексті інтерперсонального підходу.

Матеріали та методи. Дослідження проводилось 3 допомогою відкритого інтерв'ю в два етапи - при вступі до навчального закладу на спеціальність «Психологія» та по завершенню першого курсу. В першому етапі взяли участь близько 50 абітурієнтів, проте для подальшого аналізу враховувались лише наративи 30 студентів, 3 яких за результатами відбору було сформовано навчальну групу та яких в кінці навчального року було досліджено повторно.

В рамках вступної співбесіди з абітурієнтами, які планували вступ на психологічну спеціальність, ми провели мотиваційне інтерв'ю, орієнтуючись на чотири головні питання:

Чому ви зробили вибір на користь психології?

Як ви уявляєте собі доброго психолога? Як виглядає його діяльність і стиль життя?

Які риси особистості йому притаманні? Чим цей образ вам привабливий?
Як ви уявляєте себе через 7 років?

Останнє питання навмисно було відкритим, передбачало місце для виявлення особистих цілей поза професійними та давало можливість краще зрозуміти ідентичність абітурієнта.

Ми виходили 3 припущення, що мотивація абітурієнтів до навчання буде доволі незріла в тому сенсі, що фантазійний елемент домінуватиме над реалістичною оцінкою своїх можливостей, реальним станом справ в професії та реалій сьогодення. Крім того, ми розуміли, що людині в 16 років навряд чи вистачить зрілості належно усвідомити перспективу свого рішення та взяти відповідальність за своє бажання. Для порівняння, на Заході студент остаточно обирає свою фахову спеціалізацію аж в 21 рік, тобто на виході з пубертату, коли (его-) ідентичність вже відносно викристалізувана та стабілізована. До цього часу віна здобуває освіту, йдучи за своїми інтересами, підбираючи основний масив (університетських/ коледжних) навчальних курсів та спецкурсів на власний розсуд. Відтак, підліток має час i простір для мораторію - випробування різних версій своєї ідентичності. В таких умовах захоплення філософією, наприклад, може вкластись в один-два семестри, поступово зміщуючись у менш екстравагантному напрямку. Якщо ж ні, то в 21 рік це вже буде достатньо усвідомлений вибір, продиктований не стільки підлітковим імпульсом, скільки справжнім покликанням, узгодженим з основами харак- 
теру людини.

На жаль, в Україні професійний вибір підліток повинен здійснити на 6 років швидше, як мінімум в 11 класі, коли постає питання про репетиторів. Більше того, це рішення переважно стає незворотнім. Спеціальній профорієнтації та профдіагностиці школа не приділяє серйозної уваги. В українській системі післяшкільної освіти немає гнучкості та простору для мораторію - періоду можливих проб i змін. Підліток з легкістю може потрапити в пастку власного вибору. Те, що було для нього життєвою потребою в 16, абсолютно вичерпує себе в 20 чи в 30 років. Тому у стількох людей освіта та подальша робота розщеплюються в абсолютно різні площини.

Саме тому нам важливо було зрозуміти стартову мотивацію абітурієнтів з тим, щоб відстежити їі зміни в динаміці та оцінити можливості інтерперсонального впливу в системі студент - викладачі / університетська структуpa.

Результати досліджень та їх обговорення. Аналіз текстів інтерв'ю в експертній групі психотерапевтів дав нам можливість виокремити такі мотиваційні профілі.

У першому профілі можна виділити мотив нарцизму. Домінує курс на кар'єру, привабливість діяльності вимірюється в категоріях фінансового успіху та соціального впливу. Бажаним полем є сфера HR та менеджменту, максимальною привабливістю наділяється робота в ІТ-галузі. Доволі відкрито декларуються прагматичні цінності (дієвість, орієнтація на ситуацію, практичність), навчання мислиться як опанування набором необхідних технологій.

Другий профіль містить непряму ціль скористатися навчанням на психології для вирішення власних особистісних проблем. Його можна влучно описати в категоріях адлеріанського комплексу неповноцінності та гіперкомпенсації. Домінує ідея 3 допомогою спеціальних знань здобути бажану комунікативну компетентність та соціальну привабливість. Разом 3 тим, професійна перспектива формулюється доволі неясно, а від навчання очікується доступ до втаємничених рецептів лайфхакінгу.

Третій профіль схожий в тому сенсі, що теж передбачає використання навчання на психології передусім в особистісних цілях. Однак тут домінує ідентифікаційний мотив та мотив причетності до привабливого світу цікавих творчих i «просунутих» людей. Часто цей світ протиставляється батьківським уявленням про гідну професію та обирається всупереч їх пересторогам. Психологія сприймається як богемна діяльність, а навчання на психології змальовується як філософськоестетична пригода. Абітурієнти цього профілю здебільшого начитані або в інший спосіб обізнані з психологічними течіями та персоналіями, зокрема психоаналізом та Фройдом, мають власні, часто поверхові, однак претензійно сформульовані рефлексії про них. Щодо уявлень про навчання, то вони налаштовані на 
занурення в світ елегантних ідей, глибини персонального досвіду та творчих експериментів, чого точно бракує іншим спеціальностям. У цій групі часто зринає ідея про майбутню терапевтичну діяльність, звучить мотив, зорієнтований на допомогу іншим людям. Сфера психології управління при цьому ігнорується або й відверто знецінюється як маніпуляція. Умовно ми називаємо цей профіль естетичноекспірієнтальним.

Четвертий профіль притаманний абітурієнтам, що займають доволі інфантильну позицію, яка однак ніяк не корелює з інтелектуальними можливостями. Їх вибір майбутнього фаху диктований радше зовнішніми чинниками, як от рішення батьків, привабливість закладу, наслідування вибору подруг тощо. Інтерес до психології вторинний, а очікування від майбутнього навчання доволі скупі та формальні. Образ майбутньої діяльності невиразний, стереотипний. Характерною $є$ плутанина уявлень про роботу практичного психолога та соціального педагога.

Останній профіль, який нам вдалося виокремити, умовно можна назвати дифузний. Домінує ідея про вищу освіту, а не про конкретну спеціальність. Тут ключовим маркером $\epsilon$ розгубленість щодо власного вибору, власних бажань та власної перспективи, при чому ця розгубленість може артикулюватися як відверто, так і агресивно, через напад. Наприклад, висловлюється переконаність, що в сучасному світі більшість людей не працюють за фахом, тож нема різниці, яку саме освіту здобувати. Навчання розцінюється як необхідність, проте особистісної заангажованості нема.

Узагальнюючи, варто наголосити, що всі мотиваційні профілі в тій чи в іншій мірі грунтувались на нереалістичних уявленнях як про психологічну діяльність як таку, так і про навчання.

Тож через рік, по завершенню першого курсу, ми зробили коротке інтерв'ю з студентами, яке було задумане як форма зворотного зв'язку та рефлексії про навчальний досвід. 3 його допомогою ми змогли валідизувати наші спостереження за студентами протягом навчального року, описати проблемні особливості їх навчальної мотивації в рамках їх стартового мотиваційного профілю та відрефлексувати особливості свого власного ставлення та очікувань.

Варто почати 3 того, що понад $3 / 4$ студентів пережили досвід розчарування. В більшості він був пов'язаний з навчальним контентом (дисципліни загального природничого та гуманітарного циклів, а також фундаментальні психологічні дисципліни на кшталт загальної психології). Разом з тим, їм вдалося здолати це первинне розчарування - яке в психотерапевтичних категоріях можна розцінювати як першу і необхідну фрустрацію реальності - 3 допомогою механізмів ідентифікації. Так, практично кожен студент інтуїтивно обрав собі референтну фігуру серед викладачів і за- 
вдяки довірі до неї зумів вдатися до пошуку нових реалістичніших сенсів навчання. По друге, перший курс минув в активних дискусіях довкола методів і шкіл психології, студенти виразно ділилися на когнітивістів, психоаналітиків та гуманістів, реалізуючи свою ідентифікаційну стратегію. Вже після першого семестру з'явилися ознаки автономної самодіяльності, студенти активно сканували простір на предмет практичних семінарів і студій. Таким чином, ідеалізація вивітрилась і змінилася помірним ентузіазмом, важливим і самодостатнім мотиватором навчання стали стосунки між студентами в групі. Тільки четверо студентів опинилися на межі демотивації, їх несумлінне відвідування та невиконання вимог призвело до ймовірності відрахування. Троє 3 них первинно належали до тієї групи, чий мотиваційний профіль позначався розгубленістю. Ще один студент мав нарцистичний мотиваційний профіль. У всіх чотирьох випадках викладачі задекларували одноголосну позицію - «не хочеш вчитися - не вчися і будь вільний». Таким чином, у всіх чотирьох випадках явно забракло ідентифікаційного резонансу, студенти вдалися до захисного уникання, на що викладачі зреагували відштовхуванням. Можна припустити, що жоден $з$ викладачів інтуїтивно не знайшов щодо них ані позиції «мами, яка зваблює до життя», ані вникаючого батька, який вимагає та контролює результат. Цікаво, що досвід складання сесії по талонах, що рівнозначний караючій батьківській рамці, спрацював позитивно для трьох студентів, повернувши їх з позиції ізоляції назад у стосунок і спонукавши до комунікації. На нашу думку, для студентів першого курсу на фоні різкої сепарації від школи особливо важливою стає заангажована та в міру стимулююча позиція викладачів. Інакше підліток переживатиме дочасно обірваний зв'язок, не маючи ще достатньо психологічного оснащення для самостійного буття. Ми переконані, що найгірше для підлітка - це розріджена доросла увага, особливо для такого, що сам боїться її привертати, ймовірно очікуючи афективного тиску чи бурі. Проте повна свобода та емоційна незаангажованість дорослих означатиме ще страшніший вакуум і тільки посилюватиме розгубленість і страх перед власним внутрішнім життям. Якщо бракуватиме рамок і контролю, підлітка загризе почуття провини за свої бажання та думки, і він скоїть що завгодно, лиш би скинути з себе цей тягар. Рамки натомість дають гарантію безпеки, відчуття того, що витримка та увага батьків чи батьківських фігур сильніші за його імпульсивні викиди, негативізм і відчай. Згідно з Малєр, батьки чи викладачі як субститутні фігури в пубертаті виступають джерелом підживлення в кризових ситуаціях [5].

Щодо мотиваційних амбівалентностей, які увиразнилися в рамках кожного мотиваційного профілю, можна сказати наступне. В прагматичній, зорієнтованій на успіх групі, з'явилася відверта споживацька лінія. Їй при- 
таманні принцип ринкових відносин у стосунках $з$ викладачем (тиск, намагання домовитись про вигідні умови, виконання завдань та опанування матеріалу рівно в межах домовленості), холоднокровність і виклик, який подекуди межує з психопатичними проявами (претензії до викладачів, до організації навчального процесу, емоційний шантаж і апеляція до вищих інстанцій, створення конфліктних ситуацій в ширшому контексті), маніпуляція (емоційний тиск), відсутність справжнього, буттєвого інтересу до жодної дисципліни, натомість відверта декларація інструментального ставлення. Вважаємо, що тут дуже важливо тримати загальну рамку та не піддаватися на «ногу в дверях» в надії уникнути зайвих клопотів і тривог. Ми виходимо з того, що рамки підлітку потрібні, передусім для того, щоб він мав можливість зупинитися в разі, якщо імпульс його виб'є з коридору афективної толерантності і дестабілізує. А підлітка виносить за межі власних регуляторних можливостей регулярно, адже це вік імпульсивного і незрілого драйву. Він може епатувати, очолити боротьбу за справедливість, стати антисоціальним, заглибитися в емоційну кризу, сховатися у віртуальній реальності, або $з$ надмірної напруги може сам себе контрфобійно підставити, знецінити і поставити в нарцистично програшну позицію. Оскільки він постійно ризикує схибити, йому потрібні виважені та послідовні рамки, які неможливо розхитати. Для цього передусім важлива спокійна позиція перед ти- ском параноїдно забарвлених проекцій і утримання від екстренних дій з метою уникнення відреагування та вкручуванню в маніпуляцію.

Дещо протилежними $є$ рекомендації для роботи з студентами, які на старті вирізнялися інфантильною мотивацією. Тут, навпаки, здається доречним для викладачів дотримуватися, наскільки це можливо, принципу привітної нейтральності та абстиненції, щоб не підтримувати альянсу 3 фальшивим згідливим Селф студентів. Адже незважаючи на очевидну самостійність цих студентів, їх функціональну сепарацію та сепарацію позицій в розумінні Хоффмана, емоційно вони все ще залишаються дуже залежними від батьківських реакцій, а також реакцій тих дорослих, яким батьки делегували свою функцію. Сепарація такого підлітка є обмежена материнською тривогою. Стосунок тримається на емоційному комплаєнсі з боку підлітка, і лише ізольовано, у виняткових ситуаціях вибухає лють. Чим далі, тим більше назбирується та замикається коло взаємних докорів і образ, часто не висловлених прямо, вони множаться разом $з$ дорослішанням дитини, яка все частіше воліє робити щось, що не сприяє маминому спокою. Нарешті підлітку доведеться наразитись на конфлікт, щоб могти здобувати власний досвід і не чутись при цьому винним. Хоффман називає це конфліктною сепарацією - могти приймати рішення і не мати за них вини перед батьками - і стверджує, що часто доросла та успішна в житті людина все ще провадить з батьками 
внутрішні діалоги, виправдовуючись і щось їм злісно доводячи. У випадку студентів важливо не пустити цю тенденцію в ріст, і найкращим способом це зробити стає можливість не піддатись на роль нарцистично чи тривожно очікуючої мами, а натомість зайняти привітно нейтральну й абстинентну позицію.

Цікавими є мотиваційні зміни, які відбуваються з студентами 3 профілем, зорієнтованим на гіперкомпенсацію власних труднощів і особистісних дефіцитів. Вони виявилися найбільш піддатливими до реакцій вигорання та регресії. 3 одного боку, навчальний контент є далекий від інструкції з досягнення особистісного успіху, з іншого боку, саме цей сухий академічний матеріал дає безпеку та слугує захистом від ідеї поставити себе в позицію клієнта психолога, а не студента-психолога. Звідси гостра амбівалентність і неоднозначне ставлення і до навчання, і до викладачів, що треба мати на увазі. Можливо, це саме ті студенти, які згодом знайдуться в суміжному або й зовсім чужому професійному полі або ж будуть прихованими опозиціонерами у власному, доки не опрацюють свій мотиваційний конфлікт. В цілому, ці студенти йдуть у бік когнітивної стратегії психологічного опрацювання, приймають академічну манеру за зразок і опираються всьому, що має відношення до психотерапії. В комунікації з ними, на нашу думку, важлива максимальна лояльність i терплячість до них та одночасно повага до власних меж і власної справи.
На противагу їм, студенти $з$ естетичноекспірієнтальними налаштуваннями щодо психології дуже швидко знецінюють академізм, сприймаючи його як прикру необхідність, і вдаються до найрізноманітніших психотерапевтичних практик, в тому числі освітніх проектів, часто нехтуючи віковими нормами. В цілому, вони роблять ставку на емоційний інтелект і артикуляцію власної ідентичності. Їм приманна емпатія, здатність вникати в психологічну проблематику i налаштовуватись на емоційний резонанс, однак за рахунок браку зрілої емоційної регуляції вони є особливо нарцистично вразливими. Тож ми вважаємо, що для цієї категорії студентів особливо важливим $є$ міжособистісний контекст взаємодії з викладачами. Доречною буде чутлива, виважена, емпатична позиція, можливо навіть до певної міри наставницька, а також готовність слугувати моделлю для ідентифікації.

Висновки. Таким чином, ми розглянули основні мотивації до навчання, з якими абітурієнти поступають на психологічні спеціальності, описали їх особливості та типологізували мотиваційні профілі, а також відстежили їх динамічну генезу протягом першого року навчання у ВУЗі. Ми виходили з специфіки вікової психодинаміки та розглядали ії через призму інтерперсонального підходу, а також враховували особисту заангажованість, яку 3 неухильністю викликає вибір психології як фаху, тож розглядали навчання як своєрідний майданчик для консолідаційних та диферен- 
ційних селф-процесів, пошуку та артикуляції его-ідентичності. В результаті нам вдалося сформулювати рекомендації для викладачів щодо їх оптимальної позиції в інтерперсональному полі з огляду на мотиваційний профіль конкретного студента.

\section{Перспективи подальшого досліджен-}

ня. Перспективу подальшого дослідження ми вбачаємо в тому, щоб відстежити динаміку навчальної мотивації студентів протягом 5 (6) років університетського навчання та описати іiі кульмінаційні віхи через призму перебігу селф-процесів консолідації та диференціації, а також спробувати з цієї точки зору оцінити зрілість его- та фахової ідентичності після завершення навчання в університеті.

\section{Перелік використаних джерел:}

1. Дольто Ф. На стороне подростка / Ф.Дольто. - Екатеринбург: У-фактория, - 2004.

2. Карамушка Л. М. «Прогресивні» та «консервативні» типи організаційної культури: порівняльний аналіз організаційної культури загальноосвітніх навчальних закладів традиційного та інноваційного типів / Л. М. Карамушка, А. М. Шевченко // Актуальні проблеми психології: зб. наук. праць Інституту психології імені Г.С. Костюка НАПН України / за ред. С. Д. Максименка, Л. М. Карамушки. - К. - Алчевськ: ЛАДО, - 2014. - С. 1520.

3. Кохут X. Восстановление самости / Х. Кохут. - М.: Когито-Центр, - 2002. - 320 с.

4. Коць М. О. Динамічна модель активності суб'єктів педагогічної взаємодії / М. О. Коць // Матеріали I Міжнародної науково-практичної інтернет-конференції (13 травня 2014 р.) Збірник наукових праць К-ПНУ імені
Івана Огієнка, Інституту психології імені Г.С.Костюка НАПН України / за ред. Л. В. Засєкіної, А. В. Кульчицької. - Луцьк : Вежа-Друк, - 2014. - С. 146-148.

5. Малер М., Мак-Девитт, Дж. Б. Процесс сепарациииндивидуации и формирование личности / М. Малер // Журнал практической психологи и психоанализа. 2005. - № 2. - Режим доступу: http://psyjournal.ru/j3p/ all.php.

6. Серкіс Ж. В. Про організаційну культуру закладу освіти / Ж. В. Серкіс // Практична психологія та соціальна робота. - № 9 - 10. - 2002. - С. 4-9.

7. Столороу Р. Сковывающие узы и освобождающие связи / Р. Столороу, Д. Атвуд, Б. Брандшафт // Журнал практической психологи и психоанализа. - 2000. - № 1. - Режим доступу: http://psyjournal.ru/j3p/all.php

8. Фигдор $\Gamma$. Психоаналитическая педагогика / Г.Фигдор. - М.: Издательство института психотерапии, $-2000 .-288 \mathrm{c}$.

9. Хржановски Г. Психоаналитические теории Карен Хорни, Гарри Стека Салливана и Ериха Фромма / Г.Хржановски // Енциклопедия глубинной психологии и психоанализа. Т.ІІІ. / Последователи Фрейда / Пер. с нем. под ред. А.М.Боровикова. - М., Когито-Центр, МГМ, - 2002. - $410 \mathrm{c}$.

10. Abrams $S$. Differentiation and Integration / S. Abrams // Psychoanalytic Study of the Child. - 1996. - Vol.51. - New Haven, CT: Yale University Press. - pp. 25-34.

11. Berberich E. Mapping Out the Internal World / E. Berberich, A. Bergman, P.L. Janssen, H.C. Meyers // In The Internal Mother / ed. S.Akhtar, S.Kramer, H.Parens, Northvale, NJ: Jason Aronson, 1996. - pp. 93-114.

12. Erikson E. The Challenge of Youth / Erik H. Erikson. NY: Doubleday Anchor, 1965

13. Siegler A. L. Some Thoughts on the Creation of Character / A. L. Siegler // In The Mother-Daughter Relationship: Echoes Through Time, ed. G. H. Fenchel, - Northvale, NJ: Jason Aronson, 1998. - pp. 29-44.

14. Tyson P. Object Relations, Affect Management, and Psychic Structure Formation: The Concept of Object Constancy / P. Tyson // Psychoanalytic Study of the Child. - 
2003. - Vol. 58. - New Haven, CT: Yale University Press. - pp. 190-201

15. Urdan T. Self-efficacy beliefs of adolescents / T. Urdan, F. Pajares. - Information Age Publishing, Greenwich, 2006. -380 p.

\section{References (Transliteration):}

1. Dolto F. Na storone podrostka / F.Dolto. Ekaterinburg: U-faktoriya, - 2004.

2. Karamushka L. M. «Progresyvni» ta «konservatyvni» typy organizacijnoi' kul'tury: porivnjal'nyj analiz organizacijnoi' kul'tury zagal'noosvitnih navchal'nyh zakladiv tradycijnogo ta innovacijnogo typiv / L. M. Karamushka, A. M. Shevchenko // Aktual'ni problemy psyhologii' : zb. nauk. prac' Instytutu psyhologii' imeni. G.S. Kostjuka NAPN Ukrai'ny; za red. S. D. Maksymenka, L. M. Karamushky. - K. - Alchevs'k : LADO, - 2014. - S. 15-20.

3. Kokhut Kh. Vosstanovlenye samosty / Kh. Kokhut. - M. : Kohyto-Tsentr, - 2002. - $320 \mathrm{~s}$.

4. Kots M. O. Dynamichna model aktyvnosti subiektiv pedahohichnoi vzaiemodii / M. O. Kots // Materialy I Mizhnarodnoi naukovo-praktychnoi internet-konferentsii (13 travnia 2014 r.) Zbirnyk naukovykh prats K-PNU imeni Ivana Ohiienka, Instytutu psykholohii imeni H.S.Kostiuka NAPN Ukrainy / za red. L. V. Zasiekinoi, A. V. Kulchytskoi. - Lutsk: Vezha-Druk, - 2014. - S. 146-148.

5. Maler M.. Mak-Devitt. Dzh. B. Protsess separatsiiindividuatsii i formirovaniye lichnosti / M. Maler // Zhurnal prakticheskoy psikhologi i psikhoanaliza. - 2005. - № 2. Rezhym dostupu: http://psyjournal.ru/j3p/all.php.

6. Serkis Zh. V. Pro orhanizatsiinu kulturu zakladu osvity / Zh. V. Serkis // Praktychna psykholohiia ta sotsialna robota. - № $9-10$. - 2002. - S. 4-9.

7. Stolorou R. Skovyvayushchiye uzy i osvobozhdayushchiye svyazi / R. Stolorou. D. Atvud. B. Brandshaft // Zhurnal prakticheskoy psikhologi i psikhoanaliza. - 2000. - № 1. - Rezhym dostupu: http:// psyjournal.ru/j3p/all.php

8. Figdor. G. Psikhoanaliticheskaya pedagogika / G.Figdor. - M.: Izdatelstvo instituta psikhoterapii. - 2000 . - 288 s.

9. Khrzhanovski G. Psikhoanaliticheskiye teorii Karen Khorni. Garri Steka Sallivana i Erikha Fromma / G.Khrzhanovski // Entsiklopediya glubinnoy psikhologii i psikhoanaliza. T.III. / Posledovateli Freyda / Per. s nem. pod red. A.M.Borovikova. - M.. Kogito-Tsentr. MGM. - 2002. - $410 \mathrm{~s}$.

10. Abrams S. Differentiation and Integration / S. Abrams // Psychoanalytic Study of the Child. - 1996. - Vol.51. - New Haven, CT: Yale University Press. - pp. 25-34.

11. Berberich E. Mapping Out the Internal World / E. Berberich, A. Bergman, P. L. Janssen, H. C. Meyers // In The Internal Mother / ed. S. Akhtar, S. Kramer, H. Parens, Northvale, NJ: Jason Aronson, 1996. - pp. 93-114.

12. Erikson E. The Challenge of Youth / Erik H. Erikson. NY: Doubleday Anchor, 1965

13. Siegler A. L. Some Thoughts on the Creation of Character / A. L. Siegler // In The Mother-Daughter Relationship: Echoes Through Time, ed. G. H. Fenchel, Northvale, NJ: Jason Aronson, 1998. - pp.29-44.

14. Tyson P. Object Relations, Affect Management, and Psychic Structure Formation: The Concept of Object Constancy / P. Tyson // Psychoanalytic Study of the Child. - 2003. - Vol. 58. - New Haven, CT: Yale University Press. - pp. 190-201

15. Urdan T. Self-efficacy beliefs of adolescents / $T$. Urdan, F. Pajares. - Information Age Publishing, Greenwich, 2006. -380 p. 


\section{Yaskevych Olha}

PhD, Psychology and Psychotherapy department, Ukrainian Catholic University, Lviv (Ukraine)

\section{Mykolaychuk Maryana}

PhD, Psychology and Psychotherapy department, Ukrainian Catholic University, Lviv (Ukraine)

\section{LEARNING MOTIVATION PECULIARITIES OF FIRST-YEAR STUDENTS OF PSYCHOLOGICAL SPECIALTIES}

\section{ABSTRACT}

The article is dedicated to the problem of learning motivation peculiarities of the entrants, who choose psychological specialties. Based on the empirical study, it distinguishes and depicts five motivational profiles - consumeristic, infantile, aesthetically expressive, hypercompensation and diffuse profile and tracks their development during the first year of university studies.

The analysis follows the age psychodynamics specificities of student of the first year of studying. Professional identification is understood as manifestation of wider and deeper processes of ego-identity building and validaton. It is also taken into account indispensable personal engagement, connected with decision about psychological studies. Searching for ego-identity is viewed through interpersonal and selfpsychology approach. Student's learning motivation is seen as a subjective reflection of his selfcapabilities and deficits, which have been developed in the concrete interpersonal field between him and his teachers. This relationship has clear narcissistic quality, because student tends to use it for regulation, consolidation and differentiation of his own self. It is mentioned that academics are not prone to evaluate correctly their role as developmental objects for their students, or they emphasize the contrast between university and school or on the contrary resort to direct participation in student's challenges. Both positions are not good enough, because the main task of puberty is to achieve the ability of appreciation of fantasies, cathected with inner wises and fears and reality, so both handling and neutrality will be interpreted by students as unavailability and cause deprivation of their self-object needs.

Due to this way of thinking insufficient or conflict learning motivation, such as dependent, cynical, cold, apathetic or entertaining attitude, testifies about interpersonal problem, inability of teaching collective to give appropriate feedback on student's behavior, serving as a mirror of his ambivalence or supporting his autonomy-seeking behavior.

The article contains some recommendations for teachers about optimal interpersonal position in their relation with students considering their motivational profiles.

Key words: motivational profile, egoidentity, interpersonal field, developmental objects.

(C) Яскевич O. I., Миколайчук М. I. 


\section{Яскевич Ольга Игоревна}

Кандидат психологических наук, дочент кафедры психологии Украинского католического университета, г. Львов (Украина)

\section{Миколайчук Марьяна Игоревна}

Кандидат психологических наук, доиент кафедры психологии Украинского католического университета, 2. Львов (Украина)

\section{ОСОБЕННОСТИ МОТИВАЦИИ К ОБУЧЕНИЮ СТУДЕНТОВ ПЕРВОГО КУРСА ПСИХОЛОГИЧЕСКИХ СПЕЦИАЛЬНОСТЕЙ}

Аннотация. Статья посвящена анализу особенностей мотивации к обучению, с которыми абитуриенты поступают на психологические специальности. Основываясь на эмпирическом исследовании, выделено 5 типичных мотивационных профилей, а именно: нарцистическо-потребительский, инфантильный, эстетическо-экспириентальный, ориентированный на гиперкомпенсацию, и профиль, который отображает растерянность и диффузию идентичности; отслежено их динамическое развитие на протяжении первого года обучения в ВУЗе.

Анализ построен на понимании специфики возрастной психодинамики студента первого курса. Под профессиональной идентификацией подразумевается проявление общего процесса конструирования и валидизации эго-идентичности, особенно учитывая неизбежную персональную ангажированность, с которой связан выбор психологической специальности. Поиск и артикуляция эго -идентичности, в свою очередь, рассматривается в контексте интерперсонального подхода. Следовательно, учебная мотивация студента трактуется как субъективное отражение возможностей и дефицитов его собственного Я, сложившиеся в конкретном интерперсональном поле между ним и преподавательским коллективом. Это отношение имеет выразительную нарцистическую характеристику в том смысле, что студент использует его для регуляции, консолидации и дифференциации собственного Селф. Отмечается, что преподаватели не всегда корректно оценивают свою роль в отношении к студентам в качестве развивающих объектов, противопоставляя университет школьной опекающей рамке, или, наоборот, прибегая к непосредственному участию в студенческой жизни. Обе позиции неуместны, так как основная задача пубертата научиться различать свои окрашенные желаниями и страхами представления и реальное положение вещей, поэтому и хендлинг, и нейтральная абситентность будут считываться студентом как недоступность и будут депривировать его селф-объектные запросы.

Согласно обозначенной логике, проблемная мотивация студента к обучению, которая может проявляться, например, в виде инфантильного, цинически-потребительского, развлекательно-медийного или формальнобезразличного отношения, свидетельствует об интерперсональной проблеме, неспособности университетской среды дать адекватный от- 
зыв на поведение студента, отражая ему его неуверенность, амбивалентность, или поддержать его проявления эксплорации в сторону автономии и инаковости.

В статье сформулированы рекомендации для преподавателей относительно их оптимальной позиции в интерперсональном поле, учитывая мотивационный профиль конкретного студента.

Ключевые слова: мотивационный профиль, эго-идентичность, интерперсональное поле, объект развития. 